\title{
The causes of the lack of self-tolerance of winter rye, grown on light sandy soils. 2. Influences of phytotoxins and soil microflora
}

\author{
K. Scholte and L. J. P. Kupers \\ Department of Field Crops and Grassland Husbandry, \\ Agricultural University, Wageningen, the Netherlands
}

Accepted: 12 December 1977

Key words: rye, self-tolerance, crop rotation, soil microflora, phytotoxins, soil sterilization, root growth, uptake of nitrogen, monoculture.

\section{Summary}

As a result of an investigation into the causes of self-intolerance of rye, it could be proved that a number of obvious well-known pathological agents such as nematodes, foot rots and phytotoxins cannot be accepted as important causes. Circumstantial evidence was produced strongly suggesting that the composition of the soil microflora - to a certain extent itself the result of growing this crop in the previous year - is the main cause. Soil sterilization eliminates self-intolerance. One symptom of self-intolerance is the rapid degeneration of the root system at an early stage of growth. Application of larger doses of nitrogen postpones the onset of this phenomenon. The effect of nitrogen is indirect. A larger continued uptake of nitrogen furthers the potential for compensation of the plant.

\section{Introduction}

In a rotational experiment on a light sandy soil, conducted between 1952 and 1970, it was found that winter rye is a self-intolerant crop (Scholte and Kupers, 1977). Averaged over the whole period the seed yield was more than $30 \%$ lower on the plots where rye was grown following rye compared to the yield of those plots where rye was grown after all other preceding crops in this field experiment. Straw yield was depressed by about $10 \%$.

There was no indication from the field experiments that nematodes and foot rot diseases played an important role in the depression in yield. Indications were found pointing to an impaired uptake of nitrogen by the rye-rye crops.

In pot experiments an investigation was conducted into other possible causes of the self-intolerance of rye. Special attention was paid to the action of phytotoxins and soil organisms others than nematodes and foot rots. 


\section{Experiments}

\section{Experiment 1 (1971)}

Rye was grown following the preceding crops: rye and oats (the crop preceding the first rye crop and the oats crop was in both cases potatoes). Three levels of nitrogen fertilization were used: 672,1008 and $1344 \mathrm{mg} \mathrm{N}$ per pot. The soil used in the pot experiment was untreated or steam-sterilized and the systemic fungicide Benlate was applied to control the foot rots. In this experiment two harvests were made during the growing season.

\section{Experiment 21973}

Rye was grown in pasteurized soil, to which had been added $3 \mathrm{~g}$ chopped and dried pasteurized rye straw or $3 \mathrm{~g}$ identically treated oats straw per litre. Three nitrogen levels were used: 700,1750 and $2800 \mathrm{mg}$ pure $\mathrm{N}$ per pot. In this experiment three harvests were made at certain stages of growth.

\section{Experiment 31975}

Rye was grown following the preceding crops of rye or oats. In both cases the pre-preceding crop was potato. Three levels of nitrogen fertilization were used: 700,1750 and $3500 \mathrm{mg}$ pure $\mathrm{N}$ per pot. The soil was either untreated or sterilized by heating. Crops were harvested at four certain stages of growth.

The soil used in Experiment 1 came from the rye and oats plots of the B rotation which had shown the self-intolerance of rye in the field experiment so clearly. Experiment 3 was conducted with soil which had been prepared in the preceding year on a field where rye and oats had been grown alongside each other. The cropping history of the soil in this experiment was identical. The soil was collected eight weeks after harvesting the preceding crop and after stubble ploughing. The soil was sieved in the laboratory in order to get rid of stones and coarse organic plant material and afterwards intensively homogenized.

The sterilization of the soil of Experiment 1 was done by heating with steam up to a soil temperature of $80-85^{\circ} \mathrm{C}$. The soil was kept at this temperature for 1 hour. Sterilization of the soil in Experiment 3 was done by dry thermal heating of the soil at $95^{\circ} \mathrm{C}$ for 1 hour. In Experiment 2, the same procedure was used but only at $70^{\circ} \mathrm{C}$ for 1 hour.

In Experiment 1 applications of Benlate, based on a quantity of $2 \mathrm{~kg} \mathrm{ha}^{-1}$, were given at stages F1, F4, F7 and F10.5 of the Feekes scale. The chopped straw used in Experiment 2 was dry-pasteurized at $70^{\circ} \mathrm{C}$ for 2 hours and intensively mixed with the pasteurized soil. The addition of $3 \mathrm{~g}$ straw per litre soil may be compared to $6000 \mathrm{~kg}$ straw ha-1.

The experiments were conducted in mitscherlich pots filled with $8 \mathrm{~kg}$ soil. The seed, variety Dominant, was treated with the normal quantity of TMTD (thiram). The nutrients were applied as solutions, given in six unequal portions from emergence until the end of flowering. In the three experiments the climate in the 
glasshouse and the growth pattern of the plants was roughly as follows:

$\begin{array}{cccc}\begin{array}{c}\text { Number of days } \\ \text { after sowing }\end{array} & \begin{array}{l}\text { Growth stage } \\ \text { (Feekes scale) }\end{array} & \begin{array}{l}\text { Day/night } \\ \text { temperature }\left({ }^{\circ} \mathrm{C}\right)\end{array} & \begin{array}{l}\text { Day length } \\ (\text { h) }\end{array} \\ 0-30 & 0-2 & 10 / 5 & 11 \\ 30-76 & 2-3 & 5 / 3 & 9 \\ 76-106 & 3-5 & 10 / 6 & 11 \\ 106-150 & 5-8 & 13 / 9 & 13 \\ 150-180 & 8-10.5 & 15 / 11 & 15 \\ 180-195 & 10.5-10.5 .4 & 20 / 15 & 16 \\ 195-245 & 10.5 .4-11.3 & 17 / 15 & 16\end{array}$

\section{Results}

Production of dry matter, root weight and uptake of nitrogen (Experiment 1)

Although the pot experiments were set up in order to find the cause of the yield depression of a rotational experiment in the field, it was necessary in the first place to prove that the observations in the field could be reproduced in pots in a glasshouse.

In Table 1 the results of pot experiment 1 are compared with the results of the field experiment. From Table 1 one may conclude that the experiment in pots approximately mirrors the field experiment. The depression in seed yields is of the same order, the depression in straw yields is even more severe in the pot experiment. A reason for this effect could be that the method of nitrogen application in the pot experiment was different from the application in the field. In the field nitrogen was supplied twice in the growing season: at the start of regrowth after winter and at the end of the boot stage. In the pot experiment nutrients were supplied in six separate portions as a solution until the end of flowering. In

Table 1. Yields of rye grown in pots; variant: non-sterilized soil and without fungicide, compared to the average yield (1965-1970) of a field experiment.

\begin{tabular}{|c|c|c|c|c|}
\hline \multirow[b]{2}{*}{$\cdot$} & \multicolumn{2}{|c|}{ Pot experiment, rye after } & \multicolumn{2}{|c|}{ Field experiment, rye after } \\
\hline & oats & rye $^{1}$ & oats & rye $^{1}$ \\
\hline Seed yield² & 33.9 & $25.8(76)^{* * *}$ & 3018 & $2192(73)^{* * *}$ \\
\hline Straw weight² & 64.2 & $55.0(86)^{* * *}$ & 5686 & $5225(92)^{*}$ \\
\hline Number of ears ${ }^{3}$ & 23.1 & $20.4(88) * * *$ & 315 & $269(85)^{* * *}$ \\
\hline Number of grains per ear & 46.0 & $41.7(91)^{* * *}$ & 34.2 & $32.7(96)$ \\
\hline 1000-grain weight $(\mathrm{g})$ & 31.8 & $30.6(96)^{*}$ & 33.8 & $29.5(87)^{* * *}$ \\
\hline
\end{tabular}

1 In parentheses the yield of rye after rye as a percentage of the yield of rye after oats.

${ }^{2}$ In $\mathrm{g} \mathrm{dm}$ per pot and $\mathrm{kg} \mathrm{dm}$ per ha.

3 Number per pot and number per $\mathrm{m}^{2}$.

* $\mathrm{P} \leqslant 0.05 ; * * \mathrm{P} \leqslant 0.001$. 


\section{LACK OF SELF-TOLERANCE OF WINTER RYE}

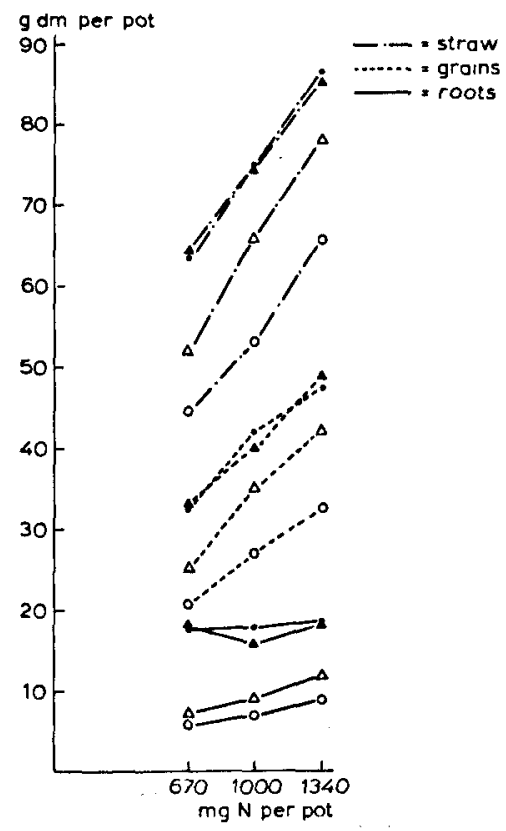

Fig. 1. Dry matter weight of grains, straw and roots of rye in relation to nitrogen level, soil treatment and preceding crop (Experiment 1). Open symbols: untreated soil; black symbols: treated soil; circles: preceding crop rye; triangles: preceding crop oats.

Experiment 1 two harvests were made, the first one week after flowering, the second in the dead ripe crop. Only the results of the final harvest are presented in Table 1 though there is no difference in tendency between the results of the two harvest dates.

Fig. 1 shows how the dry matter $(\mathrm{dm})$ weight of seed, straw and roots is related to nitrogen fertilization. At every level of nitrogen in untreated soil the rye-rye variant produced less seed, straw and roots than the oats-rye variant. In sterilized soil this difference in productivity completely disappears.

Fig. 2 shows how the quantity of nitrogen taken up by the plants is related to the quantity supplied. In untreated soil the rye-rye variant takes up less nitrogen from the soil than the oats-rye variant. Again, not such a difference was found in sterilized soil. Sterilization of the soil eliminates the influence of the preceding crop.

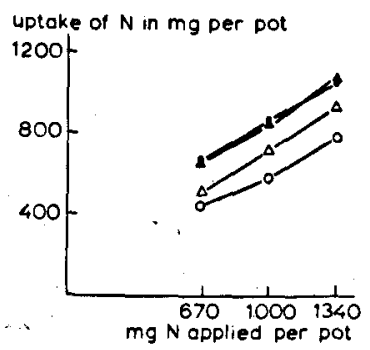

Fig. 2. Uptake of nitrogen by rye in relation to nitrogen level, soil treatment and preceding crop (Experiment 1). For explanation of symbols, see Fig. 1. 


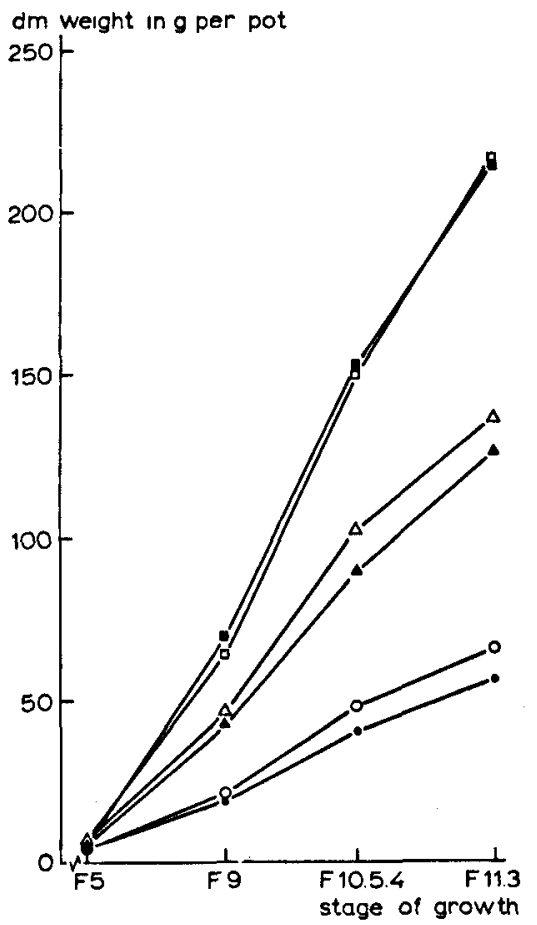

Fig. 3. Sprout growth of rye in untreated soil in relation to preceding crop and nitrogen level (Experiment 3). Black symbols: preceding crop rye; open symbols: preceding crop oats; circles: $\mathrm{N}_{1}$; triangles: $\mathrm{N}_{2}$; squares: $\mathrm{N}_{3}$.

Dry matter production, root weight and uptake of nitrogen during the growing period (Experiment 3)

The results from Experiment 1 have led to the question of at what date in the growing period the yield depression sets in. The number of harvests (at fixed growth stages) and the quantity of nitrogen supplied were considerably increased in Experiment 3.

In Fig. 3 the growth curves for rye grown after either rye or oats at three levels of nitrogen fertilization in untreated soil are shown. At the end of the tillering stage (F5) measurable differences could not be found; but in the jointing and early boot stage, the first signs of a stagnation in growth of the rye-rye variant became visible at least at the two lower nitrogen levels. This stagnation continued during the rest of the growing period and led to an evident depression in yield. At the highest nitrogen level the variant rye-rye seemed to be unaffected by the rotational sequence. Very high nitrogen application seems to further the potential for compensation

In Fig. 4 the growth curve of rye in sterilized soil is presented. In experiments such as Experiment 1 soil sterilization causes a complete disappearance of the rotational effect.

Fig. 5 shows the root dry weights of the variants in untreated soil. At the end of the tillering stage (F5) the preceding crop did not have any effect; but at the second harvest date (F9) the rye-rye variant at the lowest nitrogen level had reached an evidently lower root weight than the oats-rye variant. The nitrogen 


\section{LACK OF SELF-TOLERANCE OF WINTER RYE}

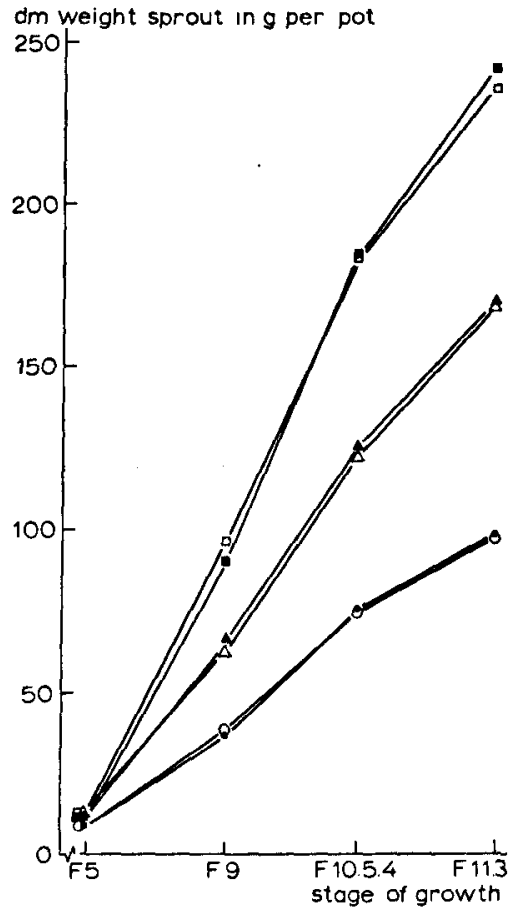

Fig. 4. Sprout growth of rye in sterilized soil in relation to preceding crop and nitrogen level (Experiment 3). For explanation of symbols, see Fig. 3.

levels 2 and 3 at this moment did not show this clear difference. At the third harvest date at the end of flowering (F10.5.4), the rye-rye variant even at the second nitrogen level had a reduced root weight compared to the oats-rye variant. At the highest nitrogen level there was still no difference. At final harvest, however, even the highest nitrogen level of the rye-rye varant finally reacted to the rotational stress with a reduced root weight in the last part of the growing period. Nitrogen seems to have a retarding action on the degeneration of the root system.

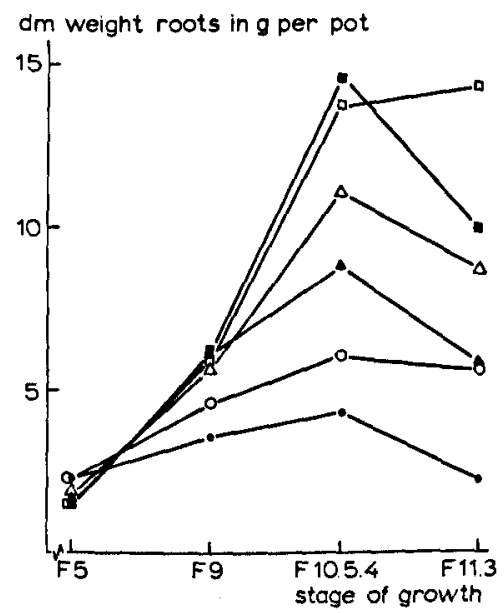

Fig. 5. Root growth of rye in untreated soil in relation to preceding crop and nitrogen level (Experiment 3). For explanation of symbols, see Fig. 3. 
Table 2. The 'quality' of the roots at final harvest. For the scale, see text.

\begin{tabular}{|c|c|c|c|c|c|c|c|c|}
\hline \multirow[t]{2}{*}{ Preceding crop } & \multicolumn{4}{|c|}{ Untreated soil } & \multicolumn{4}{|c|}{ Sterilized soil } \\
\hline & $\mathrm{N}_{1}$ & $\mathrm{~N}_{2}$ & $\mathbf{N}_{3}$ & mean & $\mathbf{N}_{1}$ & $\mathrm{~N}_{2}$ & $\mathrm{~N}_{3}$ & mean \\
\hline Oats & 3.0 & 3.0 & 2.8 & 2.9 & 4.8 & 4.6 & 3.4 & 4.3 \\
\hline Rye & 1.2 & 1.2 & 1.8 & 1.4 & 4.0 & 4.0 & 3.2 & 3.7 \\
\hline Mean & 2.1 & 2.1 & 2.3 & 2.2 & 4.4 & 4.3 & 3.3 & 4.0 \\
\hline
\end{tabular}

Root weight is only one aspect used to measure the potential of functions of the roots system. In order to give an extra dimension to the weight of the roots, all variants were also classified according to a scale for colour and resilience at final harvest. Table 2 gives this information. The scale runs from 1 to 5 . A greyish, easily broken root mass has the lowest score and a resilient, lightly coloured, root system reaches score 5 .

At final harvest the roots of the untreated rye-rye variant consisted mainly of the thicker blackish and very brittle roots. All the finer branches had disappeared. The oats-rye variant still had a more or less complete root system; resilience was still satisfactory but the colour was brown. The periodical harvests had shown that in the rye-rye variant discoloration appeared earlier than in the oats-rye variant. Soil sterilization not only affected root weight positively (Fig. 6) but at final harvest the roots were of a healthy colour. At the two lower nitrogen levels the oats-rye variant was better than the rye-rye variant (Fig. 12).

Fig. 7 shows the uptake of nitrogen from untreated soil. At a low nitrogen

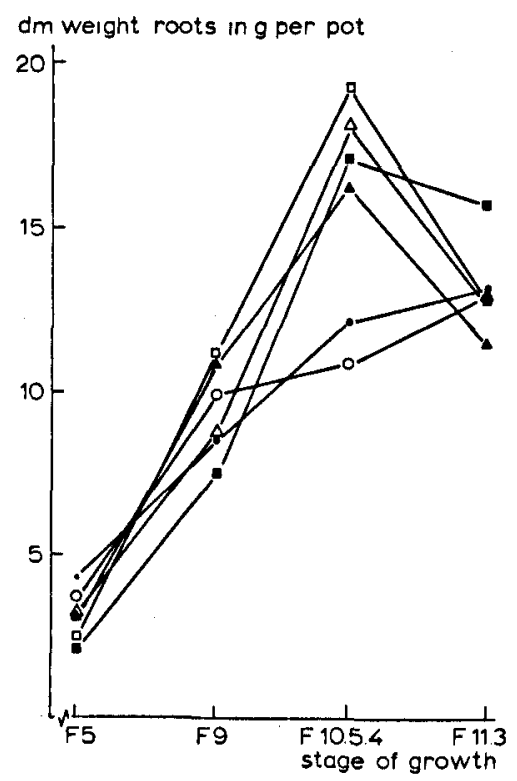

Fig. 6. Root growth of rye in sterilized soil in relation to preceding crop and nitrogen level (Experiment 3). For explanation of symbols, see Fig. 3. 


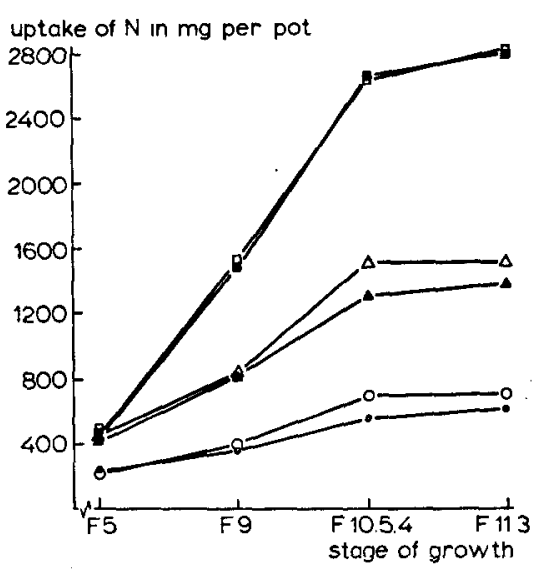

Fig. 7. Uptake of nitrogen by rye in untreated soil in relation to preceding crop and nitrogen level. (Experiment 3). For explanation of symbols, see Fig. 3.

level the uptake stagnated early in the season. At the middle nitrogen level the stagnation in uptake started later in the season and at the highest level no difference could be measured. In sterilized soil (Fig. 8) no significant differences in uptake of nitrogen due to rotational effects could be found.

\section{Foot rots (Experiment 1)}

In Experiment 1 the degree of foot rot attack was scored in a disease index. This index is the percentage of the severely attacked culms plus half the percentage of slightly attacked culms. Control of foot rots was done by means of an application of Benlate. The results are given in Table 3. In untreated soil without the fungicide treatment the foot rot attack is more severe in the rye-rye variant than in the oats-rye variant. Treatment with fungicide eliminates the difference.

The first and somewhat surprising result in Table 3 is that soil sterilization did not prevent foot rots. Bollen (1974) found that sterilized soil is very rapidly recolonized by micro-organisms by way of airborne spores. The character of the

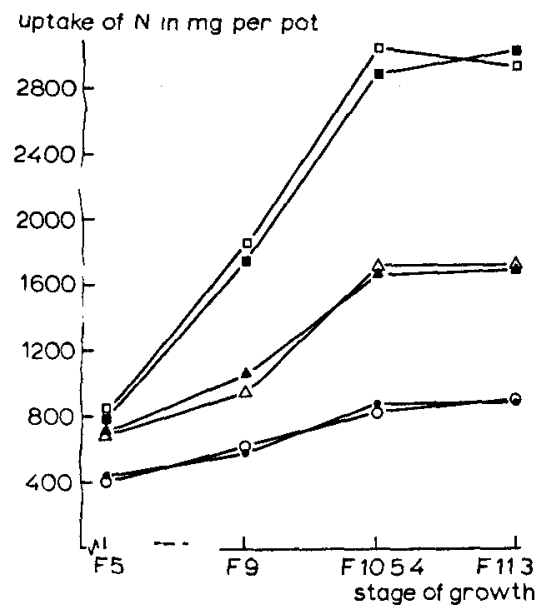

Fig. 8. Uptake of nitrogen by rye in sterilized soil in relation to preceding crop and nitrogen level (Experiment 3). For explanation of symbols, see Fig. 3. 
Table 3. The disease index and the seed yield of rye averaged over the three nitrogen levels.

\begin{tabular}{|c|c|c|c|c|c|c|c|}
\hline \multirow{3}{*}{$\begin{array}{l}\text { Stage of growth } \\
\text { Preceding crop }\end{array}$} & \multirow{3}{*}{$\begin{array}{l}\rightarrow \\
\rightarrow\end{array}$} & \multicolumn{4}{|c|}{ Disease index } & \multicolumn{2}{|c|}{ Seed yield (g dm /pot) } \\
\hline & & \multicolumn{2}{|c|}{ F10.5 } & \multicolumn{2}{|c|}{ F11.3 } & \multicolumn{2}{|c|}{ F11.3 } \\
\hline & & oats & rye & oats & rye & oats & rye \\
\hline Untreated soil & $\begin{array}{l}-\mathrm{F}^{1} \\
+\mathrm{F}\end{array}$ & $\begin{array}{l}32.2 \\
27.6\end{array}$ & $\begin{array}{l}36.5 \\
27.3\end{array}$ & $\begin{array}{l}50.8 \\
33.5\end{array}$ & $\begin{array}{l}65.5 \\
38.7\end{array}$ & $\begin{array}{l}33.9 \\
34.5\end{array}$ & $\begin{array}{l}25.8 \\
27.7\end{array}$ \\
\hline Sterilized soil & $\begin{array}{l}-F \\
+F\end{array}$ & $\begin{array}{l}25.5 \\
15.0\end{array}$ & $\begin{array}{l}25.2 \\
11.4\end{array}$ & $\begin{array}{l}32.9 \\
33.9\end{array}$ & $\begin{array}{l}42.8 \\
24.2\end{array}$ & $\begin{array}{l}40.6 \\
40.6\end{array}$ & $\begin{array}{l}40.1 \\
41.4\end{array}$ \\
\hline
\end{tabular}

$1-F=$ no fungicide $;+F=$ fungicide.

foot rot attack in sterilized soil is different from the untreated soil. In untreated soil the eye spots were mainly caused by Rhizoctonia solani. In sterilized soil brown-coloured rots were prevalent and the disease index, though still rather high, was lower than in the untreated soil. Treatment with a fungicide certainly affected the disease index but the final effect on seed yield was low. In this experiment treatment with a fungicide had no effect on the reduction in yield due to the rotation. The seed yield in Table 3 proves that in sterilized soil the rotational effect disappears.

\section{Root growth and fungicide application (Experiment 1)}

Treatment with a fungicide was done at a number of intervals by directing the spray at the base of the stems. Therefore, quite a lot of fungicide must have reached the soil surface. One may assume that some of the fungicide application was transported into the soil by leaching and possibly taken up by the roots. The fungicide could in this way have also had an effect on the presence and forms of the soil micro-organisms.

Treatment with Benlate had an evident and positive effect on root weight in all objects. In sterilized soil this effect is even larger. It is possible that the penetration of the fungicide in sterilized soils is better due to a higher permeability for water. It could be also that in sterilized soils the micro-organisms are more susceptible to the effect of the fungicide.

\section{The addition of straw to the soil}

In Experiment 2 the effect of chopped straw added to the soil was investigated. The literature suggests that phytotoxins produced in decomposing straw are the cause of the stagnation of root growth. In order to prevent infection of the soil by micro-organisms in and on the straw, the straw was dry-pasteurized and mixed with pasteurized soil. Pasteurizing at $70{ }^{\circ} \mathrm{C}$ kills the pathogens in the soil but most of the saprophytic fungi remain alive (Bollen, 1974). Van den Berg (1975) found no difference in the rate of decomposition of wheat straw in untreated and pasteurized soil 80 days after pasteurization. During this period the straw, in both treatments, had been decomposed by $40.3 \%$. Schönbeck (1956) demonstrated 


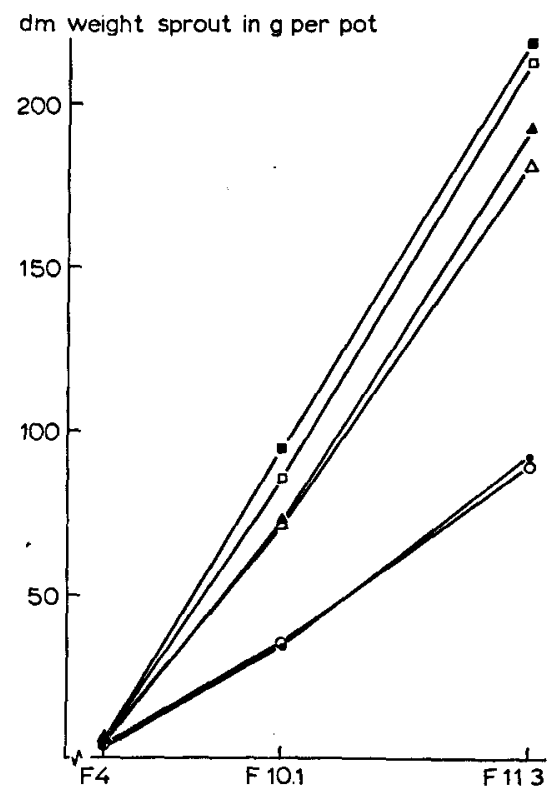

Fig. 9. Sprout growth of rye in relation to the addition of rye straw (solid symbols) and oats straw (open symbols) to the soil and the nitrogen levels (Experiment 2). Circles: $\mathrm{N}_{1}$; triangles: $\mathrm{N}_{2}$; squares: $\mathrm{N}_{3}$.

that inhibitors released from straw were not inactivated by heating at $100{ }^{\circ} \mathrm{C}$ for two hours. If it is assumed that the length of the stubble of a cereal crop is at least $10 \mathrm{~cm}$, then the weight of organic material, stubble and root which stays on the field after harvest is about $2200 \mathrm{~kg} \mathrm{ha}^{-1}$ for rye and about $2400 \mathrm{~kg} \mathrm{ha}^{-1}$ for oats (Anonymous, 1973).

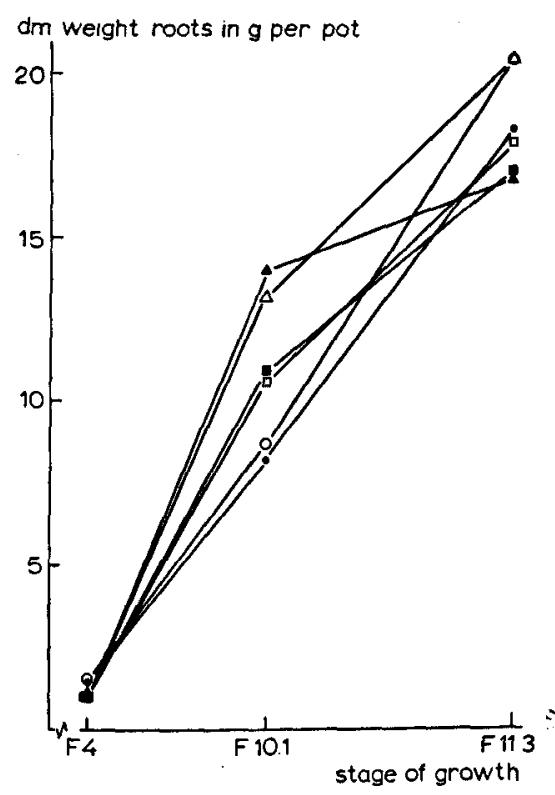

Fig. 10. Sprout growth of rye in relation to the addition of rye or oats straw to the soil and the nitrogen level (Experiment 2). For explanation of symbols, see Fig. 9. 

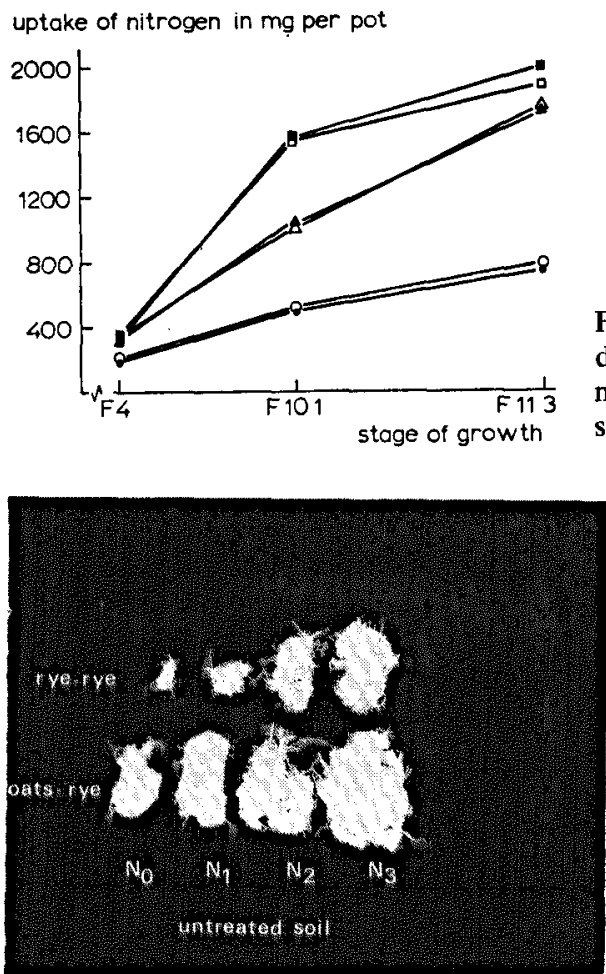

Fig. 11. Uptake of nitrogen in relation to the addition of rye or oats straw to the soil and the nitrogen level (Experiment 2). For explanation of symbols, see Fig. 9.

Fig. 12. Root mass at final harvest, dependent on soil treatment, nitrogen level and preceeding crop (Experiment 3).

In order to promote the eventual effects of the addition of straw to the soil, the equivalent of $6000 \mathrm{~kg} \mathrm{ha}^{-1}$ was added to the soil in the pots. Fig. 9, 10 and 11 show, respectively, the reactions of sprout weight, root weight and nitrogen uptake to the addition of straw. No effects were found at the start of the growth period but at the end the addition of rye straw had a significant $(\mathrm{P}<0.01)$ positive effect on sprout weight at all nitrogen levels and a slightly negative effect (not significant) on root weight. There was no difference in the uptake of nitrogen with the addition of straw in either rye or oats.

Table 4. Number of nematodes in $100 \mathrm{ml}$ soil in Experiment 3.

\begin{tabular}{|c|c|c|c|c|c|}
\hline \multirow[b]{2}{*}{ Preceding crop } & \multirow[b]{2}{*}{$\rightarrow$} & \multicolumn{2}{|c|}{ Untreated } & \multicolumn{2}{|c|}{ Sterilized } \\
\hline & & rye & oats & rye & oats \\
\hline Pratylenchus sp. & & 490 & 830 & 0 & 0 \\
\hline Tylenchorhynchus sp. & & 245 & 180 & $\mathbf{0}$ & 0 \\
\hline Meloidogine larvae & & 10 & 10 & 0 & 0 \\
\hline Heterodera trifolii larvae & & 10 & 30 & $\mathbf{0}$ & 0 \\
\hline Saprophagic nematodes & & 775 & 735 & 30 & 75 \\
\hline
\end{tabular}




\section{Nematodes}

In Experiment 3, just before sowing, soil samples were taken in order to establish the presence of nematodes. Table 4 gives the results. From this table it certainly cannot be maintained that the preceding crop rye leads to a higher population of nematodes. Sterilization of the soil was effective.

\section{Discussion}

\section{The structure of the depression in yield}

The results of the experiments in pots largely show a congruence with the outcome of the experiments in the field. In both cases the first signs of stagnation in growth occurred in the boot stage of the crop. During this stage the uptake of nitrogen by the crops of the rye-rye sequence started to falter.

The reduction in the rate of uptake was not caused by a lower supply in the soil. If the preceding crop had influenced the nitrogen supply, then this effect persisted, though on a lower level, after soil sterilization. No difference, however, is found between the variants grown after rye or oats in sterilized soil. From this it follows that the reduction in uptake of nitrogen by the rye-rye crop is caused by a reduction in the capacity for uptake.

In Experiment 3 the root system of rye grown after rye had completely deteriorated at the end of the growing period. This was far less after oats. After soil sterilization the root system, even at the end of the growing season, was still lightly coloured and springy. In Experiment 3 the deterioration of the root system of the rye-rye variants sets in after the tillering stage. According to the theory of crop science a progressively restricted uptake of nitrogen compels the plant to a redistribution of nutrients too early in the growing season. The older leaves die off prematurely. In the booting stage less tillers per plant manage to produce an ear which consequently leads to a reduction in the number of ears per unit area.

Restraints in growth during ear formation also lead to a reduction of the potential number of grains per ear. The heaviest blow to production is dealt in the grain filling stage. The deteriorating root system which also suffers from a lack of carbohydrates supplied in healthy crops by the older leaves, can no longer maintain the supply of water for production in the grain filling stage. The crop ripens prematurely. Seed yield suffers more than straw yield.

In Experiment 3 the supply of very large quantities of nitrogen effectively delayed the degeneration of the whole plant. This reaction seems to be more general in monocultures of cereals. Vez (1975) found that one of the most effective practices for reducing the depression in yield of wheat grown as a monoculture, is a strongly increased fertilization with nitrogen.

\section{Causes of yield depression}

Nematodes. In Experiment 3 the population of the nematodes, determined as species as well as in quantities, was no worse after rye than after oats. In the 
field experiments the same results were obtained so the conclusion can be drawn that in this case nematodes do not play an important role in the cause of yield depression.

Foot rots. In Experiment 1 diseases of the leaves were insignificant. The attacks by foot rots in this experiment were reasonably reduced by repeated applications of fungicide but the increase in yield was only small. If a fungicide was used, there was no longer any difference in foot rot attack whether the crop was grown after rye or after oats.

The depression in yield remained. The pot experiments confirmed the conclusion drawn from the field experiments that in this case foot rots are not the main cause of the yield depression of rye grown after rye.

The increase in yields due to the fungicide in the rye-rye variants was larger than in the rye-oats variants. It is not impossible that repeated treatments of the base of the stem with a fungicide led to a retarded degeneration of the roots of the plants. This effect was not important enough to prevent yield depression. Platenkamp \& Bollen (1973) found that the effect of an application of Benlate on the rhizosphere flora of rye is only a short-term effect.

Phytotoxins. Some investigators, including McCalla (1971), Patrick (1971), Patrick \& Koch (1958), Patrick \& Tousson (1964) and Schönbeck (1956) demonstrated in laboratory experiments that substances obtained from the extraction of decomposing plant material or from soils, have a growth inhibiting effect on germinating seeds and seedlings. The question arises as to whether, under field conditions, those substances from decomposing plant material can reach high enough concentrations to hamper the following crop, not only in the seedling stage but even when the plant is almost fully grown. McCalla extracted from soils quantities of phenolic acids which were rather too low for phytotoxic effects. He assumed that in the soil, in the direct neighbourhood of decomposing plant residues, the concentrations could be high enough to induce phytotoxicity.

Various research workers indicate that toxic substances derived from decomposing organic material are usually found in heavy, badly aerated or water logged soils. On the light sandy soil of this experiment those conditions certainly never arose. Patrick \& Tousson (1964) came to the conclusion that under more normal soil conditions, phytotoxicity of derivates from decomposing plant material seldom arises.

There are still other arguments as to why phytotoxins have not played an important part as a cause of yield depression in the rye-rye variant. In Experiment 2 in which straw of rye or oats was added to the soil in quantities far in excess of what is left as stubble in the field, the rye straw variant attained the highest sprout weight at the final harvest. This result resembles the findings of Schönbeck (1956) who found that the number of germinating seeds of rye was more reduced by an extract of oats straw than of rye straw. In the rotational experiment in the field plants per $\mathrm{m}^{-2}$ were counted four weeks after emergence in the period 1965 to 1970 . Averaged over this period the rye-rye plots had the same number 
of plants per $\mathrm{m}^{-2}$ as the plots where rye was sown after all other preceding crops.

In the described experiments in sterilized soils the yield depression of the ryerye variant was absent though the organic matter as source of phytotoxins was the same as in untreated soils.

In Experiment 3 the yield depression of rye after rye could be reduced by increased fertilization with nitrogen. Winter \& Schönbeck (1957) found that a high level of fertilization with nitrogen leads to a higher concentration of inhibiting substances in the soil, at least in the beginning, than a low level of nitrogen fertilization or no fertilization at all. In the spring the soil with the highest level of nitrogen fertilization was free from inhibitors earlier in the season. The higher concentration of inhibitors in the beginning was assumed to be caused by a more intensive decomposition of the organic material due to the larger supply of nitrogen. Later in the growing season this source of inhibitors dried up sooner. In Experiment 3 the higher nitrogen fertilization level delayed the degeneration of the root system till later in the season. If in this experiment phytotoxins really had been the cause of the yield depression, the increased supply of nitrogen should have caused an even earlier onset of the degeneration of the root system.

From these argument therefore it is not reasonable to accept phytotoxins as being an important cause of yield depression in rotational experiments at least in this investigation.

Soil micro-organisms. After the discussion of three possible categories of the causes of rotational problems, the fourth group must be considered. In principle it can be assumed that growing a crop in soil leads to a qualitative and quantitative change in the population of soil micro-organisms. The thus caused predominance of certain species and their presence in sufficiently high quantities can lead to the situation that if the same species of plant follows immediately in the otherwise not too much disturbed soil, a new equilibrium is formed but a negative one for the growth of that particular plant species.

After disturbing the microflora, as done in Experiments 1 and 3 by sterilization, the assumed influence of the preceding crop by way of its lasting effect on the microflora, is completely lost. Apparently such an induced microflora of the soil has a negative influence on root growth. In sterilized soil, root growth is remarkably superior to that in untreated soil. It is true that in sterilized soil the necessary nutrients are more abundantly available than in untreated soil (Sonneveld, 1969) but from Fig. 5 and 6 (Experiment 3; stage F5) the opposite effect is evident. In the early stages of growth, and in untreated as well as in sterilized soil, root weight is reduced by increasing nitrogen levels. In spite of this negative effects of nitrogen, root weight is appreciably higher in the rich, sterilized soil compared to root weights in untreated soil. Later in the season nitrogen has the well-known positive effect on root weight. Without doubt there are clear differences in root weight dependent on soil treatment. The arguments presented may, however, not be interpreted as a negation of the increased fertility caused by soil sterilization.

Which micro-organisms should be made responsible for the described rotational 
effects was not the purpose of the investigation in this series of experiments. Domsch et al. (1968) found that repeated cropping with wheat, peas and rape increased the presence of special species of fungi.

Domsch \& Gams (1968) demonstrated in in vitro experiments that species of fungi which were stimulated by the planting of wheat and peas, affected the root growth of these plant species negatively. The fungi 'activated' by rape were usually of the innocuous saprophytic kind. In an experiment in which potentially dangerous species of fungi were compared in their effect to well-known plant parasitic fungi, it could be demonstrated that the hemiparasitic fungi could restrict root growth as strongly as the parasitic fungi.

Menon \& Williams (1957) and Williams \& Schmitthenner $(1960,1962)$ found that the composition of the soil microflora was affected by the growing crop or by the residues of the crop. Rotation could lead to a richer and more varied soil microflora than a monoculture of the separate crops.

Stille (1957) found that filtrates of cultures of a number of parasitic and an even larger number of non-parasitic soil organisms (bacteria, streptomycetes and fungi) could damage the young roots of plants after a short period of contact. As test plants flax, peas, wheat and garden cress were used.

Filtrates of cultures of non-parasitic fungi sometimes had a surprisingly strong negative effect on root growth. This led to the idea that non-parasitic fungi, growing in high densities in this rhizosphere, can damage root growth by way of their excreted dissimilation products. The most sensitive parts of the roots are the end meristems and the zone of the root where the root hairs arise. Non-parasites are thus procuring for themselves the necessary organic matter to live on as innocuous saprophytes.

From plant physiological studies, the enormous potential of roots for adaptation and thus for compensation is known (Brouwer, 1977). The farmer in fact speculates on this potential of adaptation of the roots for instance when he applies fertilizers in the placement form. In the same manner the depression in yield due to rotational causes can be attenuated by playing on this potential for compensation. In Experiment 3 the increase in nitrogen fertilization leads to a temporary postponement of the degeneration of the root system and so to a lessening of the yield depression.

Increasing nitrogen fertilization must lead to a relative increase in sprout weight but at the same time it also leads to an absolute increase of root weight in the later stages of growth. Such a large root system can keep up its functions for a longer period against the attacks of predators. When, as in cereals, the rate of root growth gradually declines as a consequence of development, the potential for regeneration also disappears. In Experiment 3 the high nitrogen fertilization level could not prevent the collapse of the root system at final harvest. The seed yield did not react in this way. The plants in the glasshouse were not subjected to stresses such as water deficits.

In the field, where stresses of any kind are the rule, even plants well supplied with nitrogen and other nutrients cannot withstand water stress for a long period on the basis of a withering root system. In the field, yield depressions cannot be 
completely avoided. A more practical aspect is that an early and large application of nitrogen increases the danger of lodging which is usually the greater risk. The results of Vetter \& Schöneich (1969) with spring wheat confirm our findings with rye as test plant. They found that the roots of monoculture wheat deteriorated early in the growing season and they also found that the roots of wheat in rotation functioned well at the same growing stage. The difference between these authors and the gist of this report is that Vetter \& Schöneich explained the effect on the root system as being caused by root inhibiting substances (phenols) formed by the decomposition of lignin containing organic material in the stubble rests. In Experiment 2 this explanation was not confirmed.

At the end of the discussion the investigated rotational problem, which as far as could be established is not caused by well described phytopathological agents, is placed on the doorstep of the mycologists. The methods of investigation of the crop scientist fails to give a more detailed answer to the problem.

\section{Conclusions}

1. The symptoms of depression in yield of rye, known as self-intolerance, are visible as degeneration of the root system at an early stage of growth.

2. It seems improbable that phytotoxins, arising from decomposing organic matter, at this stage of growth can significantly cause the degeneration of the root system.

3. In the series of experiments described, the circumstantial evidence points in the direction of a direct effect of soil micro-organisms. This effect leads to the early degeneration of the root system.

Growing rye in a soil seems to influence the soil flora in a direction which is detrimental if the same crop is grown on that field consecutively.

4. Increasing the level of the nitrogen supply leads to a reduction in the yield depression. This effect is caused by a retarding of the degeneration process.

5. The self-intolerance of rye completely disappears if the soil is sterilized by applying heat.

\section{References}

Anonymous, 1973. Handboek voor de akkerbouw, deel 2. Publ. Proefstn Akkerb. (LelystadWageningen) No. 10:31.

Berg, G. A. van den, 1975. De invloed van selectieve warmtebehandeling (pasteurisatie en sterilisatie) op enige biologische processen in kasgrond. Rapport, Proefstation voor de Groente- en Fruitteelt onder Glas, Naaldwijk.

Bollen, G. J., 1974. Fungal recolonization of heat-treated glasshouse soils. Agro-Ecosystems 1: 139-155.

Brouwer, R., 1977. Environmental effects on crop psysiology, p. 229-245.

Domsch, K. H., E. Weber \& W. Gams, 1968. Der Einfluss verschiedener Vorfrüchte auf das Bodenpilzspektrum in Weizenfeldern. Z. PflErnähr. Bodenk. 119 (1) 134-149.

Domsch, K. H. \& W. Gams, 1968. Die Bedeutung vorfruchtabhängiger Verschiebungen in der Bodenmikroflora. I. Der Einfluss von Bodenpilzen auf die Wurzelentwicklung von Weizen, Erbsen und Raps. Phytopath. Z. 63: 64-74. 
McCalla, T. M., 1971. Studies on phytotoxic substances from soil micro-organisms and crop residues at Lincoln, Nebraska. Biochemical interactions among plants. National Academy of Science, USA.

Menon, S. K. \& L. E. Williams, 1957. Effect of crop, crop residues, temperature, and moisture on soil fungi. Phytopathology 47: 559-564.

Patrick, Z. A., 1971. Phytotoxic substances associated with the decomposition in soil of plant residues. Soil Sci. 111 (1) 13-18.

Patrick, Z. A., T. A. Tousson \& L. W. Koch, 1964. Effect of cropresidue decomposition products on plant roots. An. Rev. Phytopath. 2: 267-292.

Patrick, Z. A. \& L. W. Koch, 1958. Inhibition of respiration, germination, and growth by substances arising during the decomposition of certain plant residues in the soil. Can.J. Bot. 36: 621-647.

Platenkamp, R. G. H. \& G. J. Bollen, 1973. The effect of benomyl sprays on the root mycoflora of rye. Acta bot. Neerl. 22: 168-169.

Scholte, K. \& L. J. P. Kupers, 1977. The causes of the lack of selftolerance of winter rye, grown of light sandy soils. 1. Influence of foot rots and nematodes. Neth. J. agric. Sci. 25: 255-262.

Schönbeck, F., 1956. Untersuchungen über Vorkommen und Bedeutung von Hemstoffen in Getreiderückständen innnerhalb der Fruchtfolge. Z. PflPath. PflSchutz 63: 513-545.

Sonneveld, C., 1969. De invloed van stomen op de stikstofhuishouding van de grond Tuinb. Meded. 32: 197-203.

Stille, B., 1957. Schädigungen an Pflanzenwurzeln durch Kulturfiltrate von Mikroorganismen. Arch. Mikrobiol. 26: 71-82.

Vetter, H. \& G. Schöneich, 1969. Sommerweizen-Monokultur im Vergleich zu Sommerweizen in Fruchtfolge. SchrReihe landw. Fak. Univ. Kiel.

Vez, A., 1975 Essay en vue d'attenuer les effects de la monoculture sur blé l'application de diverses mesures culturales. Revue suisse A gric. 7 (5) 153-158.

Williams, L. E. \& Schmitthenner, 1960. Effect of growing crops and crop residues on soil fungi and seedling blights. Phytopathology 50: 22-25.

Williams, L. E. \& Schmitthenner, 1962. Effect of crop rotation on soil fungus populations. Phytopathology 52: 241-247.

Winter, A. G. \& F._Schönbeck, 1957. Untersuchungen über den Einfluss von Sticktoff auf den Abbau von Hemmstoffen aus Getreidestroh und -stoppeln. Z. Pfl. Ernähr., Düngung Bodenk. 79 (124) 132-142. 